\title{
STRATEGI PEMBELAJARAN TERPADU MENYIMAK DAN BERBICARA DI PERGURUAN TINGGI
}

\author{
Iqbal \\ Sekolah Tinggi Keguruan dan Ilmu Pendidikan Muhammadiyah Bone \\ Jalan Abu Daeng Pasolong 62 Watampone \\ email: iqbal.stkipbone@gmail.com.
}

\begin{abstract}
Integrated Learning Strategies of Listening and Speaking in Higher Education. This study aimed to describe the planning, the implementation, and evaluation of the implementation of integrated learning strategies to improve student learning of listening and speaking. The research design is a classroom action research. Data was obtained from one teacher, and 40 sophomore students of Indonesia Language Education Department of Muhammadiyah STKIP in Bone. The research results showed that; (1) the planning of integrated learning strategies can improve the students learning of listening and speaking. (2) the implementation of integrated learning strategy can improve students learning of listening and speaking. Implementation steps were included; listening in pairs and cooperative learning, (3) evaluation of the integrated learning strategy can improve students learning of listening and speaking. It should be in line with the context of the content, real and factual.
\end{abstract}

\begin{abstract}
Abstrak: Strategi Pembelajaran Terpadu Menyimak dan Berbicara di Perguruan Tinggi. Penelitian ini bertujuan mendeskripsikan perencanaan, pelaksanaan, dan evaluasi penerapan strategi pembelajaran terpadu dalam meningkatkan pembelajaran menyimak dan berbicara mahasiswa. Penelitian ini adalah penelitian tindakan kelas. Data bersumber dari 1 dosen dan 40 mahasiswa Jurusan Pendidikan Bahasa Indonesia semester III STKIP Muhammadiyah Bone. Hasil penelitian menunjukkan (1) perencanaan strategi pembelajaran terpadu dapat meningkatkan pembelajaran menyimak dan berbicara mahasiswa; (2) pelaksanaan pembelajaran terpadu dapat meningkatkan pembelajaran menyimak dan berbicara mahasiswa. Langkah-langkah pelaksanaan, meliputi: menyimak berpasangan dan cooperative learning; (3) evaluasi pembelajaran terpadu dapat yang meningkatkan pembelajaran menyimak dan berbicara mahasiswa harus sejalan dengan konteks isi, aktual, dan faktual.
\end{abstract}

Kata kunci: keterampilan berbahasa, menyimak-berbicara, pembelajaran terpadu

Penguasaan keterampilan menyimak, berbicara, membaca, dan menulis melalui pembelajaran yang strategis akan turut membantu mahasiswa dalam mengikuti seluruh mata kuliah. Berdasarkan pertimbangan tersebut, tidak berlebihan kalau dikatakan bahwa penguasaan aspek-aspek keterampilan berbahasa sangat penting dalam kegiatan berbahasa.

Rusdin (2000: 3) dalam dalam penelitiannya menemukan bahwa para perancang materi pengajaran bahasa dalam menyusun GBPP hanya berdasarkan pengetahuan dan pengalaman yang dimiliki serta kemampuan intuisi dan kurang didasari oleh suatu hasil penelitian, maka hasilnya belum memenuhi tujuan dan kebutuhan belajar bahasa.

Berdasarkan hasil observasi awal peneliti ditemukan bahwa dosen kurang memahami penerapan strategi pembelajaran bahasa Indonesia khususnya pembelajaran keterampilan menyimak dan berbicara secara terpadu. Kekurangtahuan para dosen semester III STKIP Muhammadiyah Kabupaten Bone mengenai penerapan strategi pembelajaran bahasa Indonesia khususnya pembelajaran keterampilan menyimak dan berbicara secara terpadu merupakan faktor penyebab kurang berhasilnya pelaksanaan kegiatan pembelajaran keterampilan menyimak dan berbicara 
secara baik dan benar adalah metode pembelajaran yang diterapkan oleh dosen. Hasil pembelajaran menyimak dan berbicara secara terpadu beberapa tahun terakhir masih kurang dengan perolehan nilai rata-rata $C(2)$. Kondisi ini tentunya tidak dapat dibiarkan begitu saja. Pengkajian terhadap faktor-faktor penyebabnya serta pemecahan masalah dalam pembelajaran keterampilan menyimak dan berbicara secara terpadu perlu secepatnya dilaksanakan.

Berdasarkan data empiris di lapangan, khususnya di STKIP Muhammadiyah Kabupaten Bone, ketidakmampuan mahasiswa menyimak dan berbicara disebabkan oleh kurang strategi mengajar dosen yang tidak sesuai dengan minat belajar mahasiswa sehingga menimbulkan kejenuhan belajar. Oleh karena itu, untuk mengantisipasi hal tersebut, peneliti terinspirasi melakukan penelitian yang memfokuskan pada masalah teknik pembelajaran terpadu. Hal ini dilakukan karena penelitian yang relevan belum pernah dilakukan pada tingkat perguruan tinggi.

Penelitian terdahulu hanya dilakukan secara terpisah, yakni yang dilakukan oleh Halimah (2006) tentang penerapan pembelajaran kooperatif tipe STAD dalam pembelajaran berbicara pada siswa kelas X SMA Negeri 1 Campalagian Kabupaten Polewali Mandar. Hasil penelitian ini menunjukkan bahwa pembelajaran dengan menggunakan strategi STAD sangat efektif dilakukan dalam pembelajaran berbicara di SMA. Selanjutnya, Hasanuddin (2007) meneliti pembelajaran keterampilan berbicara dengan teknik Inquiry siswa kelas XI SMA Negeri 6 Makassar. Hasil penelitian tersebut menyimpulkan bahwa penggunaan teknik inkuiri dapat meningkatkan kemampuan berbicara siswa yang meliputi ketepatan pengucapan, intonasi, pemilihan kata (diksi), dan kelancaran berbicara.

Penelitian bertujuan mendeskripsikan perencanaan, pelaksanaan, dan evaluasi strategi pembelajaran terpadu dalam meningkatkan pembelajaran menyimak dan berbicara mahasiswa Jurusan Pendidikan Bahasa Indonesia semester III STKIP Muhammadiyah Kabupaten Bone.

\section{METODE}

Penelitian ini adalah penelitian tindakan kelas (Classroom Action Research). Penelitian dilaksanakan pada Jurusan Pendidikan
Bahasa Indonesia dan Sastra Indonesia Semester III STKIP Muhammadiyah Kabupaten Bone. Kegiatan penelitian ini melibatkan dosen bahasa Indonesia semester III sebagai mitra dalam kegiatan perencanaan, pelaksanaan dan evaluasi. Penelitian dilaksanakan selama enam minggu. Peneliti bertindak sebagai pengamat dan pewawancara. Mahasiswa yang yang menjadi subjek penelitian berjumlah 40 orang.

Untuk mendapatkan data yang akurat, penulis menggunakan teknik pengumpulan data melalui: (1) wawancara, yaitu teknik wawancara terstruktur untuk mencari data tentang penerapan strategi pembelajaran menyimak dan berbicara bahasa Indonesia secara terpadu, meliputi pendekatan metode, materi, tujuan pengajaran, dan latihan berbicara; (2) observasi, yaitu pengamatan langsung terhadap penerapan strategi pembelajaran menyimak dan berbicara bahasa Indonesia secara terpadu; dan (3) dokumentasi terhadap bahan pembelajaran yang digunakan dosen dalam pembelajaran. Data yang diperoleh dianalisis dengan menggunakan analisis dekriptif.

\section{HASIL DAN PEMBAHASAN}

\section{Siklus I}

Perencanaan disusun oleh peneliti dan dosen dalam pelaksanaan pembelajaran untuk meningkatkan pembelajaran menyimak. Perencanan peneliti dan dosen adalah menyusun SAP yang di dalamnya tergambar materi yang sesuai dengan tujuan pembelajaran, tema wacana, media pembelajaran, metode pembelajaran, yakni kooperatif learning dan metode SCRIPT, dan lembar penilaian (observasi dan alat evaluasi), alokasi waktu, yakni tiga kali pertemuan.

Penerapan strategi pembelajaran terpadu dalam meningkatkan pembelajaran menyimak dan berbicara dilakukan oleh peneliti dan dosen selama tiga kali pertemuan. Materi pertemuan pertama adalah mahasiswa menyimak konsentrasi dan kritis. Pada pertemuan kedua aspek berbicara, yakni mahasiswa menelaah pokok-pokok yang disimak pada pertemuan sebelumnya, lalu menugasi mahasiswa secara bergantian mengomunikasikan secara lisan. Materi pertemuan ketiga adalah mahasiswa membuat catatan selama proses menyimak, lalu didiskusikan hal yang dialami dalam menyimak. Tahap-tahap pelaksanaan kegiatan pembelajaran disesuaikan de- 
ngan skenario pembelajaran yang telah disusun seperti kegiatan awal, inti, dan akhir. Hal ini tampak berikut ini.

\section{Pertemuan Pertama}

Tujuan pembelajaran pada pertemuan pertama adalah mahasiswa mampu menyimak konsentrasi dan kritis sehingga memahami informasi penting yang disimak. Langkah-langkah pembelajaran pertemuan pertama, yaitu kegiatan awal dosen, yaitu: (1) dosen memberikan motivasi dan apersepsi serta menyampaikan tujuan pembelajaran dengan metode mengajar kooperatif learning dan metode SCRIPT; (2) dosen (peneliti) menjelaskan skenario dan aturan-aturan pembelajaran metode kooperatif learning dan metode SCRIPT.

Kegiatan inti terdiri atas beberapa tindakan dosen, yaitu (1) dosen membentuk kelompok secara heterogen yang terdiri atas empat orang; (2) dosen memberikan penjelasan tentang hakikat menyimak, menyimak konsentrasi dan kritis; (3) dosen menginstruksikan setiap anggota kelompok berpasangan (dua orang); (4) dosen memperdengarkan bahan simakan; (5) mahasiswa secara berpasangan menyimak bahan yang diperdengarkan oleh dosen; (6) mahasiswa mencatat pokok-pokok penting yang didengar dari bahan simakan; (7) mahasiswa mendiskusikan hasil simakan dalam bimbingan dosen; (8) mahasiswa dan dosen menyimpulkan pokok penting dari bahan simakan. Pada kegiatan akhir, dosen menyimpulkan pembelajaran dan memberikan tugas kepada mahasiswa.

\section{Pertemuan Kedua}

Tujuan pembelajaran pada pertemuan kedua adalah mahasiswa mampu menelaah pokokpokok yang disimak pada pertemuan sebelumnya, lalu menugasi mahasiswa secara bergantian mengomunikasikan secara lisan. Dalam hal ini, mahasiswa diharapkan mampu berbicara (mengomunikasikan informasi yang telah disimak).

Langkah-langkah pembelajaran pertemuan kedua sesuai dengan tujuan pembelajaran menelaah pokok-pokok yang disimak pada pertemuan sebelumnya, lalu menugasi mahasiswa secara bergantian mengomunikasikan secara lisan tampak pada kegiatan awal, inti, dan akhir. Kegiatan awal dosen, yaitu: (1) dosen memberikan moti- vasi dan apersepsi serta menyampaikan tujuan pembelajaran dengan metode mengajar kooperatif learning, SCRIPT, diskusi debat, dan tanya jawab; (2) dosen menjelaskan skenario dan aturan-aturan pembelajaran metode mengajar kooperatif learning, SCRIPT, diskusi debat, dan tanya jawab.

Kegiatan inti terdiri atas beberapa tindakan dosen, yaitu: (1) dosen mengorganisasikan kelompok yang telah terbentuk pada pertemuan sebelumnya yang terdiri atas empat orang; (2) dosen mengingatkan kembali kepada mahasiswa tentang tugasnya yang lalu; (3) dosen menginstruksikan setiap anggota kelompok berpasangan (dua orang); (4) dosen menugasi mahasiwa menelaah pokok-pokok yang disimak pada pertemuan sebelumnya, lalu menugasi mahasiswa secara bergantian mengomunikasikan secara lisan; (5) mahasiswa memberikan komentar dan tanggapan berdasarkan hasil yang dikomunikasikan oleh mahasiswa lain; (6) mahasiswa dan dosen menyimpulkan materi pembelajaran. Pada kegiatan akhir, dosen menyimpulkan pembelajaran dan memberikan tugas kepada mahasiswa.

\section{Pertemuan Ketiga}

Tujuan pembelajaran pada pertemuan ketiga adalah mahasiswa mampu membuat catatan selama proses menyimak, lalu didiskusikan hal yang dialami dalam menyimak. Dalam hal ini, mahasiswa diharapkan mampu berbicara (mengomunikasikan informasi yang telah disimak).

Langkah-langkah pembelajaran pertemuan ketiga sesuai dengan tujuan pembelajaran, yakni mahasiswa membuat catatan selama proses menyimak, lalu didiskusikan hal yang dialami dalam menyimak.tampak pada kegiatan awal, inti, dan akhir. Kegiatan awal dosen, yaitu: (1) dosen mengorganisasikan kelompok yang telah terbentuk pada pertemuan sebelumnya yang terdiri atas empat orang; (2) dosen mengingatkan kembali kepada mahasiswa tentang tugasnya yang lalu; (3) dosen menginstruksikan setiap anggota kelompok mencermati kembali tugas dan kegiatan pembelajaran yang telah dilakukan pada pertemuan sebelumnya; (4) dosen menugasi mahasiswa membuat catatan selama proses menyimak, lalu didiskusikan hal yang dialami dalam menyimak; (5) secara bergantian, kelompok menyajikan hasil catatan selama proses menyimak; (6) mahasiswa memberikan komentar dan tanggap- 
an berdasarkan hasil catatan kelompok lain; dan (7) mahasiswa dan dosen menyimpulkan materi pembelajaran.

Pada kegiatan akhir, dosen menyimpulkan pembelajaran dan memberikan penghargaan kepada mahasiswa yang memiliki keaktifan sangat baik selama pembelajaran.

\section{Siklus II}

Perencanaan pembelajaran dirancang oleh peneliti dan dosen serta melibatkan mahasiswa. Hal ini dilakukan setelah menelaah hasil yang diperoleh pada siklus I. Pengamatan dilakukan terhadap kegiatan dosen dan mahasiswa dalam pembelajaran berbicara, yakni penggunaan teknik debat topik dalam pembelajaran keterampilan berbicara pada aspek kebahasaan, yaitu: ketepatan lafal, ketepatan pilihan kata, dan keefektifan kalimat, dan aspek nonkebahasaan yaitu: kefasihan/ kelancaran, keterbukaan, relevansi, keberanian, dan ketenangan dalam berbicara.

Pelaksanaan pembelajaran siklus II hampir sama dengan siklus I dengan lebih mengoptimalkan pelaksanaannya dengan banyak menuntun, memotivasi, mengarahkan, dan memberi penghargaan bagi mahasiswa yang mmeeproleh hasil yang baik.

Penerapan strategi pembelajaran terpadu dalam meningkatkan pembelajaran menyimak dan berbicara dilakukan oleh peneliti dan dosen selama tiga kali pertemuan. Materi pertemuan pertama adalah mahasiswa menyimak konsentrasi dan kritis. Pada pertemuan kedua aspek berbicara, yakni mahasiswa menelaah pokokpokok yang disimak pada pertemuan sebelumnya, lalu menugasi mahasiswa secara bergantian mengomunikasikan secara lisan. Materi pertemuan ketiga adalah mahasiswa membuat catatan selama proses menyimak, lalu didiskusikan hal yang dialami dalam menyimak.

Tahap-tahap pelaksanaan kegiatan pembelajaran disesuaikan dengan skenario pembelajaran yang telah disusun seperti kegiatan awal, inti, dan akhir. Hal ini tampak berikut ini.

\section{Pertemuan Pertama}

Kegiatan inti terdiri atas beberapa tindakan dosen, yaitu: (1) dosen membentuk kelompok secara heterogen yang terdiri atas empat orang; (2) dosen memberikan penjelasan tentang hakikat menyimak, menyimak konsentrasi dan kritis; (3) dosen menginstruksikan setiap anggota kelompok berpasangan (dua orang); (4) dosen memperdengarkan bahan simakan; (5) mahasiswa secara berpasangan menyimak bahan yang diperdengarkan oleh dosen; (6) mahasiswa mencatat pokok-pokok penting yang didengar dari bahan simakan; (7) mahasiswa mendiskusikan hasil simakan dalam bimbingan dosen; (8) mahasiswa dan dosen menyimpulkan pokok penting dari bahan simakan. Pada kegiatan akhir, dosen menyimpulkan pembelajaran dan memberikan tugas kepada mahasiswa.

\section{Pertemuan Kedua}

Kegiatan inti terdiri atas beberapa tindakan dosen, yaitu: (1) dosen mengorganisasikan kelompok yang telah terbentuk pada pertemuan sebelumnya yang terdiri atas empat orang; (2) dosen mengingatkan kembali kepada mahasiswa tentang tugasnya yang lalu; (3) dosen menginstruksikan setiap anggota kelompok berpasangan (dua orang); (4) dosen menugasi mahasiswa menelaah pokok-pokok yang disimak pada pertemuan sebelumnya, lalu menugasi mahasiswa secara bergantian mengomunikasikan secara lisan; (5) mahasiswa memberikan komentar dan tanggapan berdasarkan hasil yang dikomunikasikan oleh mahasiswa lain; (6) mahasiswa dan dosen menyimpulkan materi pembelajaran. Pada kegiatan akhir, dosen menyimpulkan pembelajaran dan memberikan tugas kepada mahasiswa.

\section{Pertemuan Ketiga}

Tujuan pembelajaran pada pertemuan ketiga adalah mahasiswa mampu membuat catatan selama proses menyimak, lalu didiskusikan hal yang dialami dalam menyimak. Langkah-langkah pembelajaran pertemuan ketiga sesuai dengan tujuan pembelajaran, yakni mahasiswa membuat catatan selama proses menyimak, lalu didiskusikan hal yang dialami dalam menyimak tampak pada kegiatan awal, inti, dan akhir. Kegiatan awal dosen, yaitu: (1) dosen mengorganisasikan kelompok yang telah terbentuk pada pertemuan sebelumnya yang terdiri atas empat orang; (2) dosen mengingatkan kembali kepada mahasiswa tentang tugasnya yang lalu; (3) dosen menginstruksikan setiap anggota kelompok men- 
cermati kembali tugas dan kegiatan pembelajaran yang telah dilakukan pada pertemun sebelumnya; (4) dosen menugasi mahasiswa membuat catatan selama proses menyimak, lalu didiskusikan hal yang dialami dalam menyimak; (5) secara bergantian, kelompok menyajikan hasil catatan selama proses menyimak; (6) mahasiswa memberikan komentar dan tanggapan berdasarkan hasil catatan kelompok lain; dan (7) mahasiswa dan dosen menyimpulkan materi pembelajaran. Pada kegiatan akhir, dosen menyimpulkan pembelajaran dengan memberikan penghargaan kepada mahasiswa yang memiliki keaktifan sangat baik selama pembelajaran.

\section{PEMBAHASAN}

\section{Temuan Siklus I}

Perubahan proses dan hasil belajar pada akhir siklus ini mahasiswa sudah memperlihatkan aktivitas yang cukup baik dalam belajar kelompok, seperti mahasiswa yang belum mengerti sudah mulai bertanya kepada teman kelompoknya atau dosennya begitu pula mahasiswa yang sudah mengerti dengan tulus memberikan bimbingan kepada temannya sampai mengerti, mahasiswa yang mengajukan diri mengerjakan soal di papan tulis dan motivasi untuk belajar meningkat. Sampai pada pertemuan akhir siklus satu setelah diadakannya tes akhir siklus satu terlihat terjadi peningkatan pada hasil belajar mahasiswa dengan nilai rata-rata yang dicapai mahasiswa masih kurang. Namun, hal yang belum maksimal pada siklus I adalah dosen kurang menuntun mahasiswa secara kelompok dan individu dalam belajar serta pemberian penguatan yang kurang.

Berdasarkan pelaksanaan siklus I, tampak bahwa proses pembelajaran berlangsung selama tiga kali pertemuan dengan menggunakan pendekatan integratif dalam pembelajaran keterampilan menyimak dan berbicara. Pertemuan pertama menekankan pada kemampuan menyimak konsentrasi dan kritis, pertemuan kedua menekankan pada kemampuan menelaah bahan simakan dan mengomunikasikannya secara lisan, pertemuan ketiga menekankan pada kegiatan mendiskusikan hasil yang diperoleh dari menyimak serta seluruh kejadian yang dialami dalam proses menyimak.
Berdasarkan hasil observasi, dinyatakan bahwa penggunaan pendekatan integratif dalam pembelajaran keterampilan menyimak dan berbicara masih perlu diterapkan pada kegiatan pembelajaran baik aspek kebahasaan maupun aspek nonkebahasaan. Hasil analisis refleksi mahasiswa terhadap tanggapan yang diberikan tentang strategi integratif yang dilaksanakan dalam proses pembelajaran berbicara dan menyimak pada umumnya kurang senang karena strategi ini baru didapatkan selama proses pembelajaran. Mahasiswa hanya mendengarkan atau menyimak informasi dan mengerjakan latihan-latihan yang diberikan oleh dosen. Strategi ini hanya berpusat pada dosen dan mahasiswa hanya vakum di dalam pembelajaran.

Penerapan strategi integratif selama siklus I belum membuat mahasiswa menjadi aktif dalam proses pembelajaran, ada perasaan takut terhadap dosen maupun tugas yang diajukan. Kemampuan menyimak mahasiswa dinilai masih kurang yang disebabkan oleh materi simakan yang sulit dipahami serta strategi pembelajaran secara terpadu, yakni menyimak berpasangan yang dipadukan dengan belajar kooperatif yang belum mampu diikuti oleh mahasiswa.

Keberanian berbicara mahasiswa berdasarkan bahan simakan yang diberikan ternyata tidaklah mudah karena mereka harus mengetahui langkah-langkah atau teknik berbicara sehingga mahasiswa belum berani mengajukan tanggapan atas masalah yang diajukan. Ketenangan mahasiswa dalam berbicara belum tampak. Masih banyak ragu-ragu, terbata-bata, kaku, terburu, dan tidak mampu mengatur tempo dalam berbicara. Pada aspek keterbukaan juga belum tampak pada mahasiswa saat berbicara. Masih banyak hal yang perlu diungkapkan dan kritisi oleh mahasiswa saat berbicara sebagai pengembangan gagasan dalam berkomentar. Hal ini tidak didukung oleh keberanian dan kepercayaan diri mahasiswa. Pada aspek relevansi antara komentar dan masalah masih juga masih kurang. Dalam hal ini, belum banyak mahasiswa yang mampu menyesuaikan antara masalah yang didiskusikan dengan tanggapannya. Artinya, kadang ada tanggapan mahasiswa yang keluar dari masalah yang diperdebatkan.

Pada aspek kebahasaan seperti ketepatan lafal, ketepatan pilihan kata, dan keefektifan kalimat juga sangat kurang. Masih banyak mahasis 
wa yang berbicara dengan lafal yang kurang jelas, pilihan kata kurang tepat, dan kalimat yang diungkapkan masih bahasa santai sehingga jauh dari keefektifan kalimat. Secara umum dinyatakan bahwa rata-rata tindakan dan aktivitas mahasiswa dalam pembelajaran menyimak dan berbicara dikategorikan belum maksimal, seperti keaktifan mahasiswa menyimak masih kurang, keaktifan mahasiswa bekerja sama dalam kelompok masih kurang, keberanian menyampaikan dan melaporkan tugas masih kurang.

Berdasarkan hasil pengamatan penulis, pembelajaran penerapan pembelajaran menyimak dan berbicara secara terpadu dengan memadukan strategi menyimak berpasangan dengan cooperative learning untuk kegiatan menyimak dan diskusi debat untuk berbicara dapat meningkatkan motivasi dan gasil belajar mahasiswa. Kelompok belajar terdiri atas golongan mahasiswa berprestasi yang tinggi dengan rendah yang dipasangkan. Masalah yang dialami oleh mahasiswa, bukan menjadi masalah pribadi, melainkan menjadi masalah besama dan diselesaikan secara kelompok pasangan.

Berdasarkan hasil analisis deskriptif nilai menyimak mahasiswa Jurusan Pendidikan bahasa Indonesia semester III STKIP Muhammadiyah Kabupaten Bone siklus I dikategorikan sangat rendah. Hal ini dinyatakan berdasarkan nilai yang diperoleh mahasiswa dalam menyimak. Tidak ada mahasiwa yang memperoleh nilai $\mathrm{A}$ yang berada pada kategori sangat tinggi. Mahasiswa yang memperoleh nilai B atau kategori tinggi sebanyak 1 orang (2,5\%), mahasiswa yang memperoleh nilai $\mathrm{C}$ atau kategori sedang sebanyak 8 orang $(20 \%)$, mahasiswa yang memperoleh nilai D atau kategori rendah sebanyak 14 orang (25\%), dan mahasiswa yang memperoleh nilai $\mathrm{E}$ atau kategori sangat rendah sebanyak 17 orang $(42,5 \%)$. Dengan demikian, secara objektif dinyatakan bahwa rata-rata mahasiswa belum lulus pada mata kuliah menyimak pada pokok bahasan menyimak efisien.

Pada aspek berbicara siklus I, menunjukkan penerapan strategi pembelajaran terpadu belum meningkatkan pembelajaran berbicara aspek kebahasaan (ketepatan lafal, ketepatan pilihan kata, dan keefektifan kalimat) mahasiswa Jurusan Pendidikan Bahasa Indonesia semester III STKIP Muhammadiyah Kabupaten Bone siklus I dikategorikan sangat rendah. Hal ini dinyatakan berdasarkan nilai yang diperoleh mahasiswa dalam berbicara aspek kebahasaan (ketepatan la- fal, ketepatan pilihan kata, dan keefektifan kalimat). Hanya $1(2,5 \%)$ mahasiwa yang memperoleh nilai A yang berada pada kategori sangat tinggi. Mahasiswa yang memperoleh nilai $\mathrm{B}$ atau kategori tinggi sebanyak 2 orang $(5,0 \%)$, mahasiswa yang memperoleh nilai $\mathrm{C}$ atau kategori sedang sebanyak 3 orang $(7,5 \%)$, mahasiswa yang memperoleh nilai $\mathrm{D}$ atau kategori rendah sebanyak 7 orang (17,5\%), dan mahasiswa yang memperoleh nilai $\mathrm{E}$ atau kategori sangat rendah sebanyak 27 orang $(67,5 \%)$. Dengan demikian, secara objektif dinyatakan bahwa rata-rata mahasiswa belum lulus pada mata kuliah berbicara aspek kebahasaan (ketepatan lafal, ketepatan pilihan kata, dan keefektifan kalimat). Dalam hal ini, mahasiswa belum mampu mengomunikasikan dan mendiskusikan melalui teknik diskusi debat bahan atau materi yang telah disimak.

Pada aspek nonkebahasaan (kefasihan/ kelancaran, keterbukaan, relevansi, keberanian, dan ketenangan) mahasiswa Jurusan Pendidikan Bahasa Indonesia semester III STKIP Muhammadiyah Kabupaten Bone siklus I juga masih kurang. Hasil analisis deskriptif menunjukkan penerapan strategi pembelajaran terpadu dalam meningkatkan pembelajaran berbicara aspek nonkebahasaan (kefasihan/ kelancaran, keterbukaan, relevansi, keberanian, dan ketenangan) mahasiswa Jurusan Pendidikan Bahasa Indonesia semester III STKIP Muhammadiyah Kabupaten Bone siklus I dikategorikan sangat rendah. Hal ini dinyatakan berdasarkan nilai yang diperoleh mahasiswa dalam berbicara aspek nonkebahasaan (kefasihan/ kelancaran, keterbukaan, relevansi, keberanian, dan ketenangan). Tidak ada mahasiswa $(0 \%)$ yang memperoleh nilai $\mathrm{A}$ yang berada pada kategori sangat tinggi. Selain itu, tidak pula yang memperoleh nilai B atau kategori tinggi (0\%), mahasiswa yang memperoleh nilai $\mathrm{C}$ atau kategori sedang sebanyak 9 orang $(22,5 \%)$, mahasiswa yang memperoleh nilai $\mathrm{D}$ atau kategori rendah sebanyak 6 orang (15\%), dan mahasiswa yang memperoleh nilai $\mathrm{E}$ atau kategori sangat rendah sebanyak 25 orang $(62,5 \%)$. Dengan demikian, secara objektif dinyatakan bahwa rata-rata mahasiswa belum lulus pada mata kuliah berbicara aspek nonkebahasaan (kefasihan/ kelancaran, keterbukaan, relevansi, keberanian, dan ketenangan). Dalam hal ini, mahasiswa belum mampu mengomunikasikan dan mendiskusikan melalui teknik diskusi debat bahan atau materi yang telah disimak yang disertai oleh gerak kinesik, seperti kefasihan/ kelancaran, 
keterbukaan, relevansi, keberanian, dan ketenangan.

\section{Temuan Siklus II}

Penerapan pendekatan integratif meningkatkan pembelajaran keterampilan menyimak dan berbicara. Hal ini tampak pada setiap pertemuan yang mengalami perubahan yang sangat signifikan dibandingkan siklus I. Pada pertemuan pertama yang menekankan pada kemampuan menyimak konsetrasi dan kritis, pertemuan kedua menekankan pada kemampuan menelaah bahan simakan dan mengomunikasikannya secara lisan, pertemuan ketiga menekankan pada kegiatan mendiskusikan hasil yang diperoleh dari menyimak serta seluruh kejadian yang dialami dalam proses menyimak.

Penerapan strategi integratif selama siklus II membuat mahasiswa menjadi aktif dalam proses pembelajaran, tidak ada lagi perasaan takut terhadap dosen maupun tugas yang diajukan seperti siklus I. Kemampuan menyimak mahasiswa dinilai sangat baik yang disebabkan oleh materi simakan yang mudah dipahami serta strategi pembelajaran secara terpadu, yakni menyimak berpasangan yang dipadukan dengan belajar kooperatif yang sudah mampu diikuti oleh mahasiswa atas tuntunan dosen. Oleh karena itu, pembelajaran menyimak dan berbicara secara terpadu dengan menggunakan strategi yang secara terpadu pula, yaitu menyimak berpasangan dan kerja kelompok sangat baik. Dosen sebagai pengarah dan pengajar telah menjelaskan lebih rinci pelaksanaan menyimak dengan strategi tersebut. Demikian pula bahan simakan yang lebih aktual sehingga semua mahasiswa dapat lebih aktif memberikan komentar, tanggapan, dan kritik saat dilakukan diskusi.

Peningkatan kemampuan menyimak dan berbicara pada siklus II disebabkan oleh kolaborasi antara peneliti dan dosen. Kolaborasi yang dilakukan, yaitu: (1) kolaborasi peneliti dan dosen dalam merencanakan dan melaksanakan pembelajaran sangat bagus; (2) dosen menuntun mahasiswa secara kelompok dan individu dalam belajar menyimak dan berbicara; (3) materi pembelajaran sangat sesuai dengan perkembangan zaman, aktual sehingga memudahkan mahasiswa dalam berpikir kritis dan mengungkapkan secara kritis pula; (4) variasi dan struktur kelas diubah pada siklus II; (5) cara pelaksanaan strategi me- nyimak berpasangan dan kerja kelompok secara terintegrasi pada siklus II telah dijelaskan oleh dosen dengan baik sehingga mahasiswa mudah mengikuti langkah pelaksanaannya; (6) cara pelaksanaan pembelajaran berbicara dengan strategi diskusi debat secara terintegrasi pada siklus II telah dijelaskan oleh dosen dengan baik sehingga mahasiswa mudah mengikuti langkah pelaksanaannya; (7) dosen memberikan penilaian dan penghargaan yang sangat baik bagi mahasiswa yang memiliki keaktifan sangat baik selama pembelajaran.

Kolaborasi yang baik pada siklus II menunjang keberhasilan menyimak dan berbicara. Hasil analisis deskriptif nilai menyimak siklus II menunjukkan terjadinya peningkatan ke kategori sangat tinggi. Hal ini dinyatakan berdasarkan nilai yang diperoleh mahasiswa dalam menyimak. Tidak ada mahasiwa yang memperoleh nilai $C$ atau sedang, $D$ atau rendah, dan $E$ atau sangat rendah. Nilai yang diperoleh mahasiswa rata-rata sangat tinggi atau nilai A sebanyak 33 orang $(82,5 \%)$. Selebihnya, yakni 7 mahasiswa $(17,5 \%)$ memperoleh nilai tinggi atau B. Dengan demikian, secara objektif dinyatakan bahwa ratarata mahasiswa sudah dinyatakan lulus pada siklus II untuk mata kuliah menyimak pada pokok bahasan menyimak efisien.

Pada aspek berbicara aspek kebahasaan (ketepatan lafal, ketepatan pilihan kata, dan keefektifan kalimat) mahasiswa Jurusan Pendidikan Bahasa Indonesia semester III STKIP Muhammadiyah Kabupaten Bone siklus II dikategorikan sangat tinggi. Hal ini dinyatakan berdasarkan nilai yang diperoleh mahasiswa dalam berbicara aspek kebahasaan (ketepatan lafal, ketepatan pilihan kata, dan keefektifan kalimat). Sebanyak $25(62,5 \%)$ mahasiwa yang memperoleh nilai A yang berada pada kategori sangat tinggi. Mahasiswa yang memperoleh nilai B atau kategori tinggi sebanyak 11 orang $(27,5 \%)$, tidak ada mahasiswa yang memperoleh nilai $\mathrm{C}$ atau kategori sedang, mahasiswa yang memperoleh nilai $\mathrm{D}$ atau kategori rendah sebanyak 2 orang (50\%), dan mahasiswa yang memperoleh nilai $\mathrm{E}$ atau kategori sangat rendah sebanyak 2 orang (50\%). Dengan demikian, secara objektif dinyatakan bahwa rata-rata mahasiswa sudah lulus pada mata kuliah berbicara aspek kebahasaan (ketepatan lafal, ketepatan pilihan kata, dan keefektifan kalimat). Dalam hal ini, mahasiswa ratarata sudah mampu mengomunikasikan dan men- 
diskusikan melalui teknik diskusi debat bahan atau materi yang telah disimak.

Pembelajaran berbicara aspek nonkebahasaan (kefasihan/ kelancaran, keterbukaan, relevansi, keberanian, dan ketenangan) mahasiswa Jurusan Pendidikan Bahasa Indonesia semester III STKIP Muhammadiyah Kabupaten Bone siklus II juga sangat tinggi. Hasil analisis deskriptif menunjukkan penerapan strategi pembelajaran terpadu dalam meningkatkan pembelajaran berbicara aspek nonkebahasaan (kefasihan/ kelancaran, keterbukaan, relevansi, keberanian, dan ketenangan) mahasiswa Jurusan Pendidikan Bahasa Indonesia semester III STKIP Muhammadiyah Kabupaten Bone siklus II dikategorikan sangat tinggi. Hal ini dinyatakan berdasarkan nilai yang diperoleh mahasiswa dalam berbicara aspek nonkebahasaan (kefasihan/ kelancaran, keterbukaan, relevansi, keberanian, dan ketenangan). Sebanyak 37 mahasiswa $(92,5 \%)$ yang memperoleh nilai A yang berada pada kategori sangat tinggi. Sebanyak 2 mahasiswa $(5,0 \%)$ yang memperoleh nilai $\mathrm{B}$ atau kategori tinggi, mahasiswa yang memperoleh nilai $\mathrm{C}$ atau kategori sedang sebanyak 1 orang $(2,5 \%)$, dan tidak ada mahasiswa yang memperoleh nilai $\mathrm{D}$ atau kategori rendah, serta tidak ada mahasiswa yang memperoleh nilai $\mathrm{E}$ atau kategori sangat rendah. Dengan demikian, secara objektif dinyatakan bahwa rata-rata mahasiswa sudah lulus pada mata kuliah berbicara aspek nonkebahasaan (kefasihan/ kelancaran, keterbukaan, relevansi, keberanian, dan ketenangan). Dalam hal ini, mahasiswa sudah mampu mengomunikasikan dan mendiskusikan melalui teknik diskusi debat bahan atau materi yang telah disimak yang disertai oleh gerak kinesik, seperti kefasihan/ kelancaran, keterbukaan, relevansi, keberanian, dan ketenangan.

Keberanian berbicara mahasiswa berdasarkan bahan simakan yang diberikan ternyata tidaklah sulit dilakukan karena mereka sudah mengetahui langkah-langkah atau teknik berbicara sehingga mahasiswa berani mengajukan tanggapan atas masalah yang diajukan.

Ketenangan mahasiswa dalam berbicara sudah tampak. Mahasiswa sudah menunjukkan keberaniannya dan tidak lagi muncul perasaan ragu-ragu, terbata-bata, kaku, terburu, dan mampu mengatur tempo dalam berbicara. Pada aspek keterbukaan juga sudah tampak pada mahasiswa saat berbicara. Mahasiswa sudah memiliki ide dan inspirasi secara kritis saat berbicara sebagai pengembangan gagasan dalam berkomentar. Hal ini didukung oleh keberanian dan kepercayaan diri mahasiswa. Pada aspek relevansi antara komentar dan masalah juga sangat baik. Dalam hal ini, rata-rata mahasiswa mampu menyesuaikan antara masalah yang didiskusikan dengan tanggapannya. Artinya, tanggapan mahasiswa sesuai dengan yang didiskusikan atau masalah yang diperdebatkan.

Secara umum, dinyatakan bahwa rata-rata tindakan dan aktivitas mahasiswa dalam pembelajaran menyimak dan berbicara dikategorikan siklus II sangat baik, seperti keaktifan mahasiswa menyimak, keaktifan mahasiswa bekerja sama dalam kelompok, keberanian menyampaikan dan melaporkan tugas, serta selalu muncul ide-ide dan gagasan baru dari mahasiswa saat berbicara.

Penggunaan teknik debat topik dalam pembelajaran keterampilan berbicara mendidik mahasiswa ke arah pembelajaran kontekstual. Hasil belajar diperoleh dari saling berbagi antarteman, antarkelompok, dan/ atau antarmahasiswa yang tahu kepada mahasiswa yang belum tahu. Kegiatan pembelajaran dilakukan dalam kelompok-kelompok belajar. Mahasiswa yang pandai mengajari mahasiswa yang lemah dan mahasiswa yang tahu memberi tahu mahasiswa yang belum tahu. Kegiatan saling belajar ini bisa terjadi apalagi tidak ada pihak yang dominan dalam kelompok, tidak ada pihak yang merasa segan untuk bertanya, tidak ada pihak yang menganggap paling tahu, semua pihak saling mendengarkan.

Teknik debat topik dalam pembelajaran keterampilan berbicara menekankan tujuh komponen atau pilar CTL. Kerja sama antara mahasiswa dalam satu kelompok kecil yang sifatnya heterogen. Wujud kerja sama dalam kelompok tersebut tidak hanya menekankan pada penyelesaian tugas-tugas, tetapi juga melatih mahasiswa untuk mampu memberikan dan menerima kritikan dan saran dalam bentuk lisan, serta menanamkan rasa tanggung jawab pada diri mahasiswa.

Berdasarkan hasil penelitian, pada ketepatan pelafalan untuk kegiatan siklus I rata-rata ketepatan pelafalan mahasiswa dalam berbicara masih dalam kategori kurang sekali. Setelah dilakukan tindakan berdasarkan siklus I dan II, terjadi peningkatan dari kategori kurang sekali hingga kurang dan meningkat mencapai kategori baik. 
Hasil penelitian ini menunjukkan bahwa penggunaan teknik debat topik dapat meningkatkan ketepatan pelafalan mahasiswa dalam berbicara. Hal ini terjadi karena kesempatan mahasiswa untuk berlatih berbicara dengan lafal yang tepat di dalam kelas cukup banyak. Mahasiswa juga dapat saling mengoreksi kesalahan pelafalan dalam kelompoknya. Selain itu, mahasiswa juga saling berbagi pengalaman belajar antara temannya.

Uraian hasil penelitian tentang ketepatan pilihan kata menunjukkan bahwa terjadi peningkatan ketepatan pilihan kata mahasiswa dalam berbicara setelah digunakan teknik debat topik dalam pembelajaran keterampilan berbicara. Hal ini merupakan hasil pembelajaran yang menekankan pada kerja sama antarmahasiswa dalam kelompok-kelompok kecil. Dalam kelompok-kelompok kecil tersebut, mahasiswa saling berbagi dan saling memperbaiki kesalahan pilihan kata setiap anggota kelompoknya.

Temuan dalam penelitian ini sejalan dengan uraian Keraf (2004:11) yang menyatakan bahwa untuk mewujudkan komunikasi yang baik dan harmonis, seorang pembicara harus memiliki kosakata yang luas. Kata merupakan alat penyalur gagasan. Hal ini berarti bahwa semakin banyak kata yang dikuasai seseorang semakin banyak pula ide atau gagasan yang dikuasainya dan sanggup diungkapkannya. Namun, yang perlu diperhatikan adalah cara memilih kata yang tepat untuk mengungkapkan ide dan gagasan tersebut. Pilihan kata inilah yang disebut diksi.

Pada kefasihan/ kelancaran, keterbukaan, relevansi, keberanian, dan ketenangan dalam berbicara mahasiswa, rata-rata tingkat kefasihan/ kelancaran, keterbukaan, relevansi, keberanian, dan ketenangan dalam berbicara mahasiswa berada pada kategori kurang sekali. Setelah dilakukan tindakan berdasarkan siklus I dan II, kefasihan/ kelancaran, keterbukaan, relevansi, keberanian, dan ketenangan dalam berbicara mahasiswa meningkat dari kategori kurang sekali menjadi kategori baik sekali.

Hasil penelitian kefasihan/ kelancaran, keterbukaan, relevansi, keberanian, dan ketenangan dalam berbicara mahasiswa menunjukkan bahwa kefasihan/ kelancaran, ketebukaan, relevansi, keberanian, dan ketenangan dalam berbicara mahasiswa dapat ditingkatkan dengan melalui penggunaan teknik debat topik dalam pembelajaran keterampilan berbicara. Oleh karena menggusnakan teknik debat topik dalam pembelajaran keterampilan berbicara, maka mahasiswa mendapat kesempatan yang banyak untuk praktik berbicara di dalam kelas. Di samping itu, mahasiswa juga lebih berani mengungkapkan gagasannya karena mahasiswa diberi kesempatan untuk menggunakan kata-katanya sendiri dan juga telah banyak berlatih berbicara di dalam kelompok-kelompok kecilnya.

Selanjutnya, uraian pelaksanaan pembelajaran kedua aspek berbicara, yakni aspek kebahasaan dan aspek nonkebahasaan yang dilakukan dalam penelitian ini disajikan secara rinci berikut ini. Ketepatan pelafalan mahasiswa dalam berbicara diajarkan pada siklus pertama dan siklus kedua . Hal ini dilakukan karena ketepatan pelafalan mahasiswa pada siklus pertama belum ada yang mencapai kategori baik sekali sehingga perlu diberikan pada siklus kedua. Ketepatan pilihan kata mahasiswa dalam berbicara diajarkan pada siklus pertama. Hal ini dilakukan karena ketepatan pilihan kata mahasiswa pada siklus kedua sudah mencapai kategori sedang hingga baik sekali.

Keefektifan kalimat mahasiswa dalam berbicara pada siklus pertama sampai pada siklus kedua berkategori sedang hingga baik sekali. Selanjutnya, kefasihan/ kelancaran, keterbukaan, relevansi, keberanian, ketenangan dalam berbicara mahasiswa diajarkan pada siklus pertama juga pada siklus kedua. Hal ini dilakukan karena kategori baik sekali mampu dicapai mahasiswa setelah pelaksanaan siklus kedua, sedangkan pada siklus pertama belum ada mahasiswa yang mencapai kategori baik sekali.

Berdasarkan hasil penelitian dan pemerolehan data menunjukkan bahwa penggunaan teknik debat topik dapat meningkatkan keterampilan berbicara mahasiswa yang meliputi aspek kebahasaan, yakni: ketepatan pelafalan, ketepatan pilihan kata, dan keefektifan kalimat, serta aspek nonkebahasaan, yakni: kefasihan/ kelancaran, keterbukaan, relevansi, keberanian, dan ketenangan dalam berbicara.

Ditinjau dari aspek sikap dan tingkah laku, teknik debat topik menuntun mahasiswa dalam meningkatkan keaktifan dalam belajar. Hal ini tampak dari intensitas kehadiran mahasiswa selama pertemuan. Keaktifan mahasiswa tampak pula pada antusiasme dan perhatian yang serius dalam belajar, dari awal sampai selesai. Jarang ditemukan mahasiswa yang keluar masuk dan jarang pula mahasiswa yang fokus perhatiannya pada materi lain. 


\section{PENUTUP}

Berdasarkan penyajian hasil analisis data, dapat disimpulkan hasil penelitian ini sebagai berikut: (1) perencanaan penerapan strategi pembelajaran terpadu dapat meningkatkan pembelajaran menyimak dan berbicara mahasiswa. Perencanaan dalam meningkatkan pembelajaran menyimak terdiri atas: peneliti dan dosen menyusun SAP yang di dalamnya tergambar materi yang sesuai dengan tujuan pembelajaran, tema wacana, media pembelajaran, metode pembelajaran terpadu, yakni kooperatif learning dan metode SCRIPT (menyimak berpasangan), dan lembar penilaian (observasi dan alat evaluasi), alokasi waktu, yakni tiga kali pertemuan.

\section{DAFTAR PUSTAKA}

Halimah. 2006. "Penerapan Strategi Pembelajaran Kooperatif Tipe STAD dalam Pembelajaran Berbicara pada Mahasiswa Kelas X SMA Negeri I Campalagian Kabupaten Polewali Mandar: Suatu Penelitian Tindakan Kelas". Tesis. Tidak diterbitkan. Makassar: Program Pascasarjana Universitas Negeri Makassar.

Hasanuddin. 2007. "Pembelajaran Keterampilan Berbicara dengan Teknik Inquiry Siswa Kelas XI SMA Negeri 6 Makassar: Suatu Penelitian Tindakan Kelas". Tesis. Tidak diterbitkan. Makassar: Program Pascasarjana Universitas Negeri Makassar.
Langkah-langkah pelaksanaan selama dua siklus mengikuti langkah strategi terpadu, yakni menyimak berpasangan (SCRIPT) dan cooperative learning. Mahasiswa menyimak secara berpasangan dalam kelompok dan menjawab masalah secara bekerja sama. Setelah itu, aspek berbicara diterapkan dengan menuntun mahasiswa mengomunikasikan bahan simakan melalui bentuk diskusi debat dan tanya jawab.

Bahan evaluasi menyimak dan berbicara harus sejalan dengan konteks isi yang aktual dan faktual sesuai dengan masa kini. Artinya, materi bahan simakan adalah yang sesuai dengan kondisi mahasiswa yang mempermudah untuk memahami isi dan mudah pula untuk didiskusidebatkan.

Rusdin. 2000. "Penerapan Pendekatan Komunikatif dalam Pengajaran Bahasa Indonesia di Sekolah Tinggi Agama Islam Negeri Dato Karama Palu". Tesis. Tidak diterbitkan. Makassar: PPs UNM.

Tolla, Ahmad. 1996. "Kajian Pendekatan Komunikatif dalam Pengajaran Bahasa Indonesia di SMU di Kotamadya Ujung Pandang”. Disertasi. Tidak diterbitkan. Malang: PPs IKIP Malang. 